\title{
CONTENTS OF VOLUME 33
}

V. V. ANH: See N. M. SPENCER

C. ATKINSON and C. R. CHAMPION: Some boundary-value problems for nonlinear $(N)$ diffusion and pseudo-plastic flow

P. J. BANKS: See P. BROADBRIDGE

N. G. BARTON, C.-H. LI and S. J. SPENCER: Control of a surface of discontinuity in continuous thickness

R. K. BERA and A. CHAKRABARTI: Cooling of an infinite slab in a two-fluid medium

P. BROADBRIDGE and P. J. BANKS: Exact nonlinear solution for constant-rate expression from material of finite thickness

J. R. CANNON, YANPING LIN and SHINGMIN WANG: Determination of a control parameter in a parabolic partial differential equation

A. CHAKRABARTI: See R. K. BERA

C. R. CHAMPION: See C. ATKINSON

YONGSHAO CHEN: The existence of periodic solutions for a class of neutral differential difference equations

DAVID L. CLEMENTS and ASHLEY LARSSON: Ground motion on alluvial valleys under incident plane $\mathrm{SH}$ waves

C. J. COLEMAN: On the microwave hotspot problem

R. N. DUBEY: See J. MAZUMDAR

R. R. EGUDO, T. WEIR and B. MOND: Duality without constraint qualification for multiobjective programming

LYNN H. ERBE and ZHONGCHAO LIANG: Continuation and uniqueness for generalised Emden-Fowler systems

N. K. GHOSH: A cylindrical wave-maker problem in a liquid of finite depth with an inertial surface in the presence of surface tension

I. G. GRAHAM and Y. YAN: Piecewise-constant collocation for first-kind boundary integral equations

R. E. GRUNDY: The asymptotics of extinction in nonlinear diffusion reaction equations

XIANGJIAN HE: Hopf bifurcation at infinity with discontinuous nonlinearities

JAMES M. HILL and ADRIAN H. PINCOMBE: Some similarity temperature profiles for the microwave heating of a half-space

J. R. KING: Local transformations between some nonlinear diffusion equations

SHARDA S. KOPPAR: See L. K. PATEL

A. A. LACEY and G. C. WAKE: Critical initial conditions for spatially-distributed thermal explosions

ASHLEY LARSSON: See DAVID L. CLEMENTS

C.-H. LI: See N. G. BARTON

ZHONGCHAO LIANG: See LYNN H. ERBE 
YANPING LIN: See J. R. CANNON

J. MAZUMDAR and R. N. DUBEY: A method for the study of fully developed parallel flow in straight ducts of arbitrary cross section

NEVILLE DE MESTRE: A mathematical analysis of wind effects on a long-jumper

B. MOND: See R. R. EGUDO

SIDNEY A. MORRIS and PETER J. NYIKOS: Sudden cardiac artest and a problem in topology

DAVID MUSTARD: Uncertainty principles invariant under the fractional Fourier transform

PETER J. NYIKOS: See SIDNEY A. MORRIS

L. K. PATEL and SHARDA S. KOPPAR: Some Bianchi type $\mathrm{VI}_{0}$ viscous fluid cosmological models

SHIGE PENG and JIONGMIN YONG: Determination of a controllable set for a controlled dynamic system

J. R. PHILIP: Exact solutions for redistribution by nonlinear convection-diffusion

ADRIAN H. PINCOMBE: See JAMES M. HILL

RODOLFO SALVI: The equations of viscous incompressible non-homogeneous fluids: on the existence and regularity

G. C. SANDER: Exact solutions to nonlinear diffusion-convection problems on finite domains

N. F. SMYTH: The effect of conductivity on hotspots

JOSEPH WAI HUNG SO: Inertial manifold for a reaction diffusion equation model of competition in a chemostat

N. M. SPENCER and V. V. ANH: Spectral factorisation and prediction of multivariate processes with time-dependent rational spectral density matrices

S. J. SPENCER: See N. G. BARTON

K. K. TAM: Porous medium combustion: ignition, temporal evolution, and parameter dependence

S. TANG and R. O. WEBER: Numerical study of Fisher's equation by a PetrovGalerkin finite element method

K. L. TEO and K. H. WONG: Nonlinearly constrained optimal control problems

GERARD THOMPSON: Normal forms for elements of $o(p, q)$ and Hamiltonians with integrals linear in momenta

G. C. WAKE: See A. A. LACEY

SHINGMIN WANG: See J. R. CANNON

R. O. WEBER: See S. TANG

T. WEIR: See R. R. EGUDO

P. J. WICKS: Interaction of buoyant plumes in open-channel flow

K. H. WONG: See K. L. TEO

Y. YAN: See I. G. GRAHAM

JIONGMIN YONG: See SHIGE PENG 